Short report

\title{
Herpes simplex virus specific antibody determined by immunoblotting in cerebrospinal fluid of a patient with the Guillain-Barré syndrome
}

\author{
HANS J J A BERNSEN, * ANTON M VAN LOON, $\dagger$ RIK F J POELS, ${ }^{*}$ \\ WIM I M VERHAGEN, * COR W G M FRENKEN* \\ From the Department of Neurology, Canisius-Wilhelmina Hospital, ${ }^{*}$ and the Department of Medical \\ Microbiology, $\dagger$ University of Nijmegen, The Netherlands
}

SUMMARY The Guillain-Barré syndrome is often preceded by a herpes virus infection. Herpes simplex virus, however, has rarely been observed as the causative agent. A patient is described with a herpes simplex virus infection followed by a Guillain-Barré syndrome. Immunoblotting was used to detect herpes simplex virus-specific antibodies in serum and cerebrospinal fluid.

The Guillain-Barré syndrome (GBS) is a relatively common neurological disorder. Its cause is still undetermined but the disorder has been observed to follow a variety of viral infections.' The causative viral or bacterial agent is frequently unknown. GBS has rarely been reported as following a herpes simplex virus (HSV) infection. We present a patient who developed GBS after a period of nonspecific complaints probably related to a HSV infection.

\section{Case report}

A 27 year old woman was admitted because of a persistent headache. Her complaints had started a few weeks before with a diffuse progressive headache, a sore throat and low back pain. She suffered one bout of vomiting and diarrhoea. In the week before admission an ascending weakness developed in both legs and the patient complained of numbness affecting almost the entire body, though more pronounced in the feet. The muscles of the extremities became painful. She developed slurred speech and photophobia. Fever was absent during this period. A few weeks before the onset of these complaints a close friend of the patient's son, who frequently spent time at the patient's house, had suffered from meningitis. HSV infection (type 1) was demonstrated by isolation of the virus from skin lesions

Address for reprint requests: Dr Bernsen, The Department of Neurology, Canisius-Wilhelmina Hospital, PO Box 9015, 6500 GS Nijmegen, The Netherlands.

Received 23 April 1988 and in revised form 17 December 1988 Accepted 19 December 1988 and by serology. About ten days later the patient's son suffered from a cold sore.

When admitted the patient was cooperative but tired and dysarthric. Blood pressure was $150 / 110 \mathrm{~mm} \mathrm{Hg}$, pulse was irregular at approximately $140 / \mathrm{min}$ and temperature was $36 \cdot 6^{\circ} \mathrm{C}$. Further examination revealed no abnormalities, in particular no signs of lymphadenopathy. Neurological examination revealed a mild meningism and left facial palsy; muscles were painful on palpation and strength was reduced, especially in the lower limbs. In the feet sensation was diminished for all qualities and the patient experienced tingling sensations to light touch in all limbs and the left hemiface. The tendon reflexes were brisk except for nearly absent ankle jerks. Plantar reflexes were flexor. The straightleg raising test proved positive.

Shortly after admission a severe paresis of the extremities developed and tendon reflexes universally diminished. There was a progressive left sided facial palsy. A gradually developing mild right facial palsy was observed. Persistent sinus tachycardia and dysphagia necessitated recurrent observations in intensive care.

During hospitalisation only supportive treatment was given. Five weeks after admission the patient's condition improved and four weeks later she was discharged with only a mild facial numbness and paraesthesia of the feet. The tendon reflexes of the arm were still diminished, while the tendon reflexes of the legs were nearly absent, and the plantar responses were flexor. Six months after discharge there was only minimal sensory loss in the feet and the results of the neurological examination were otherwise normal.

\section{Laboratory findings}

Laboratory test results were all in the normal range or negative. These included assays for blood cell count, serum electrolyte level, serum protein content, renal and hepatic 
function, vitamin $B_{12}$, urinary porphorin and heavy metals, antinuclear antibodies and syphilis serology. On admission cerebrospinal fluid (CSF) analysis showed a protein concentration of $1.83 \mathrm{~g} / 1$ with normal cell counts, while two weeks and five weeks later protein concentrations of $12.3 \mathrm{~g} / \mathrm{l}$ and $3.60 \mathrm{~g} / \mathrm{l}$ respectively were found, again with normal cell counts.

\section{Electrophysiology findings}

Brain-stem auditory evoked potentials were normal on both sides. The pattern-reversal visual evoked potential showed normal P100 latencies. Electromyography of weak muscles did not show fibrillations or positive sharp waves, but there was a reduced number of motor units under voluntary control. Reinnervation was seen in $25 \%$ of the motor units of the extensor digitorum brevis and anterior tibial muscles. Motor conduction velocities were reduced (median nerve fore $\operatorname{arm} 34 \mathrm{~m} / \mathrm{s}$, posterior tibial nerve $37 \mathrm{~m} / \mathrm{s}$, peroneal nerve $35 \mathrm{~m} / \mathrm{s})$. Distal motor latencies were abnormally prolonged, for example in the extensor digitorum brevis muscle after peroneal nerve stimulation $7.2 \mathrm{~ms}$, in the abductor pollicis brevis muscle after median nerve stimulation $8.0 \mathrm{~ms}$, in the flexor digitorum brevis muscle after posterior tibial nerve stimulation $6.6 \mathrm{~ms}$. Sensory conduction velocity in the sural nerve was not measurable. The Hoffmann reflex of the soleus muscle was absent while F-wave latencies were prolonged. Compound action potentials in weak muscles were considerably reduced. No distal sensory responses could be recorded in the median and ulnar nerves. The somatosensory evoked potentials after stimulation of the median nerve at the wrist showed prolonged N9 (Erb), N13 (cervical) and N20 (cortex) latencies on both sides, but a normal N13-N20 interval time. Electroencephalography showed a slightly irregular background activity, in the right frontotemporal region some slow frequency discharge $(3-4 \mathrm{~Hz})$ was observed. The background activity was interrupted several times by paroxysmal bilateral high voltage alpha-theta discharges.

\section{Virological studies}

Virus isolation and serological studies were carried out using standard procedures. For virus isolation, the patient's material was inoculated on monolayers of primary monkey kidney cells as well as on human diploid fibroblasts (Flow 2002). HSV isolations were typed by an indirect immunofluorescence assay using type-specific monoclonal antibodies. The complement-fixation test was used to examine the patient's serum and CSF for antibodies to adenovirus, mumps virus, measles virus, (para) influenza viruses and mycoplasma pneumoniae. The previous description of an enzyme-linked immunosorbent assay (ELISA, ${ }^{23}$ ) was used for serology of HSV, varicella-zoster virus and cytomegalovirus infection. Antibodies to Epstein-Barr virus were determined by the indirect immunofluorescence technique. For immunoblotting, viral antigens were separated on a $7 \%$ to $15 \%$ SDS-polyacrylamide gel. Viral proteins were blotted onto nitrocellulose using the Dunn's method. ${ }^{4}$ To detect HSV-specific antibodies in serum and CSF, nitrocellulose strips with viral antigens were incubated with the patient's serum or CSF for 18 hours at room temperature. After washing away the nonreacting material, strips were incubated with alkaline phosphatase-labelled antibodies to human IgM, IgA or IgG (Dakopatts, Denmark). The

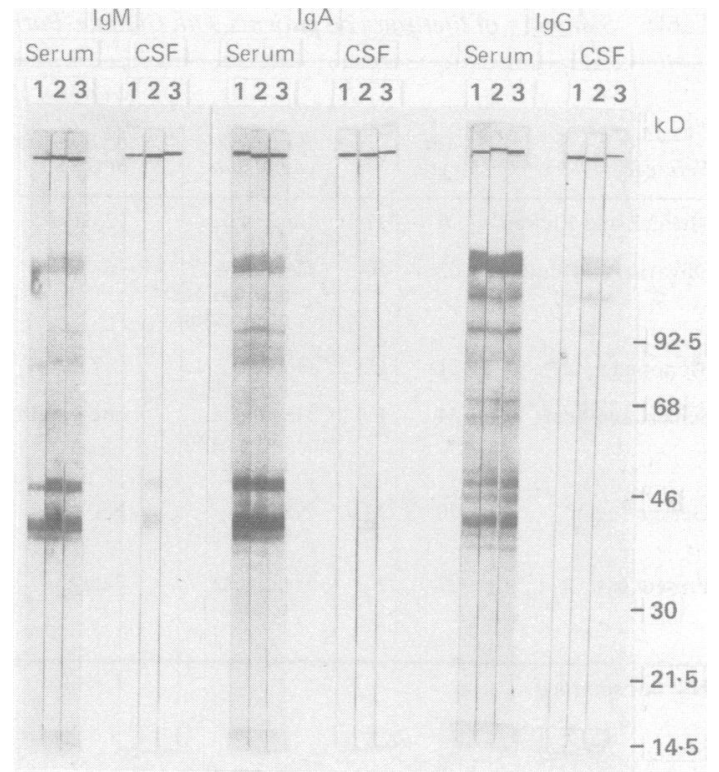

Fig Immunoblotting analysis of serum and CSF on admission (1), 2 weeks (2), and 5 weeks (3) after admission.

presence of virus-specific antibodies was subsequently visualised by reaction with substrate. ${ }^{5}$

\section{Results}

In our patient no laboratory evidence was obtained for a viral infection other than HSV. HSV itself was not isolated from CSF but HSV-specific IgM, -IgA and IgG was found in serum and CSF and included a significant rise of HSV-IgM in serum and CSF and of HSV-IgA in CSF. HSV-IgG antibody was quantitated as previously described ${ }^{2}$ and expressed in ELISA units (EU) per $\mathrm{ml}$. The concentration of HSV-IgG in the three sera obtained at the same time as CSF was 76, 68 and $68 \mathrm{EU} / \mathrm{ml}$, respectively, and 1, 10 and $3 \mathrm{EU} / \mathrm{ml}$ for the corresponding CSF specimen. The CSF/serum ratio was increased in the second and third CSF specimen since the $\mathrm{CSF} /$ serum ratio for $\mathrm{IgG}$ antibodies to adenovirus still exceeded 1:50 in these specimens. Immunoblotting analysis showed the virus specific antibodies to be mainly directed against a $42 \mathrm{kD}$ (IgM, IgA), a $48 \mathrm{kD}(\operatorname{IgM}, \operatorname{IgA})$ and a 115125 kD (IgM, IgA, IgG) viral protein (fig).

\section{Discussion}

The pathological feature of the GBS is a multifocal, noninfectious, inflammatory process affecting the peripheral nervous system. ${ }^{6}$ Immmunological, genetic and environmental factors, together with a trigger mechanism, are considered to play an important role 
Table Summary of literature on patients with Guillain-Barré syndrome and preceding HSV infection

\begin{tabular}{|c|c|c|c|c|c|c|c|c|c|}
\hline \multirow[b]{2}{*}{ Reference } & \multirow{2}{*}{$\begin{array}{l}\text { Age } \\
(y r)\end{array}$} & \multirow[b]{2}{*}{ Sex } & \multirow{2}{*}{$\begin{array}{l}\text { Preceding } \\
\text { complaints }\end{array}$} & \multirow{2}{*}{$\begin{array}{l}\text { Duration of } \\
\text { symptoms } \\
\text { before onset } \\
\text { of GBS }\end{array}$} & \multicolumn{4}{|l|}{ Clinic } & \multirow{2}{*}{$\begin{array}{l}\text { Laboratory } \\
\text { technique }\end{array}$} \\
\hline & & & & & Motor & Sensory & Cranial & Autonomic & \\
\hline Melnick and Flewett' & 6 & $\mathbf{M}$ & $\begin{array}{l}\text { Impetigo } \\
\text { Headcold }\end{array}$ & 12 days & NS & NS & NS & NS & Complement-fixation \\
\hline Olivarius and Bull's & 62 & $\mathbf{F}$ & $\begin{array}{l}\text { Headache } \\
\text { dedolations } \\
\text { of muscles, } \\
\text { fever }\end{array}$ & 6-7 days & + & + & + & - & Complement-fixation \\
\hline Menonna et $a l^{14}$ & 21 & $\mathbf{F}$ & $\begin{array}{l}\text { Herpes } \\
\text { vaginalis }\end{array}$ & \pm 7 days & + & + & + & - & $\begin{array}{l}\text { Indirect } \\
\text { immunofluorescence }\end{array}$ \\
\hline Seibert and Seals ${ }^{12}$ & 34 & $\mathbf{F}$ & $\begin{array}{l}\text { Headache, } \\
\text { neck pain, } \\
\text { genital }\end{array}$ & one month & + & + & - & - & $\begin{array}{l}\text { Virusisolation; } \\
\text { confirmed with } \\
\text { monoclonal } \\
\text { antibody }\end{array}$ \\
\hline Gerken $^{13}$ et al & 70 & $\mathbf{M}$ & NS & NS & + & + & - & - & $\begin{array}{l}\text { Complement-fixation; } \\
\text { ELISA IgM } \\
\text { antibody }\end{array}$ \\
\hline Present case & 27 & $\mathbf{F}$ & $\begin{array}{c}\text { Headache, } \\
\text { nausea }\end{array}$ & 7 days & + & + & + & + & $\begin{array}{l}\text { Antibody-capture } \\
\text { ELISA; } \\
\text { immunoblotting }\end{array}$ \\
\hline
\end{tabular}

NS: not specified.

in the development of this disease and have been discussed extensively. ${ }^{78}$ The aetiological significance of preceding infections linked to the GBS has been previously analysed by several authors. ${ }^{19-11}$ Viral infections, particularly those caused by herpes viruses such as Epstein-Barr virus and cytomegalovirus have been frequently associated with the GBS. ${ }^{9}$ To our knowledge patients with a combination of HSV and GBS have been described ${ }^{12-15}$ only rarely (table). All patients had complaints suggesting a viral infection ranging from one month to several weeks before the development of the GBS.

Each patient appeared to have had sensory or motor disturbances or both. Five patients also had cranial nerve involvement. All patients recovered although slight symptoms persisted in several cases. As in reports from the literature (table) we cannot rule out the possibility of an intercurrent infection but on reviewing the literature especially the comments concerning the relation between precedent infection and GBS we strongly believe that there may be an aetiological relationship between the GBS and the HSV infection. On the basis of serological results we assume that our patient had a reinfection. In our paper we describe a method not previously used to detect preceding viral infections in relation to the GBS.

A main problem in linking the GBS to a causative viral infection is the rather difficult diagnosis of viral infections of the central nervous system (CNS). With the exception of patients with enterovirus infection, virus isolation from the CSF is often unrewarding and laboratory diagnosis therefore mainly depends on serologic examination of CSF and serum. For this purpose we developed a sensitive ELISA for detection of HSV -IgM and -IgA in serum and CSF. ${ }^{2}$ In addition we showed that the detection of these antibodies in the CSF is indicative of a HSV infection of the CNS. HSV -IgM and -IgA were detected in the serum and CSF op our patient. To confirm and extend these findings we carried out an immunoblot analysis for HSV-specific IgM, -IgA and -IgG. HSV-specific antibodies in serumo were demonstrated agaisnt several HSV antigens particularly those in the range of $38-49 \mathrm{kD}$ and of $115-125 \mathrm{kD}$. These antibodies were found in the IgM as well as the $\operatorname{IgA}$ and IgG class, although the patterf was seen to differ in the IgG assay. Similarly, vira antibodies of the $\operatorname{IgM}, \operatorname{IgA}$ and $\operatorname{IgG}$ class were detected in CSF, albeit at lower concentrations compared to those in serum. In CSF the antibodies of the IgM and IgA class were directed mostly against the $42 \mathrm{kD}$ and $48 \mathrm{kD}$ HSV antigen whereas the IgG response was (as in serum), predominantly directed to the 115-125 kD HSV antigen probably representing the viral glycoprotein 8AB. This pattern is consistent with the observations of Eberle et $a l^{1617}$ who noticed that the strongest antipolypeptide response was directed against the $8 \mathrm{AB}$ antigen and a series of lowmolecular weight antigens in the range of 34-49 kD.

We conclude that HSV may have an important role in processes resulting ultimately in the GBS. Larger studies are necessary to confirm this relationship and immunoblotting may prove to be a valuable tool in the systematic analysis of preceding viral infections.

We thank Jan Zoll for his skilful technical assistance and Dr C G Sinha for assistance in preparing the manuscript. 


\section{References}

1 Melnick SC, Flewett Th. Role of infection in the GuillainBarré syndrome. J Neurol Neurosurg Psychiatry 1964;27:395-407.

2 van Loon AM, van der Logt JTM, Heessen FWA, van der Veen J. Use of enzyme-labeled antigen for the detection of immunoglobulin $\mathbf{M}$ and $\mathbf{A}$ antibody to herpes simplex virus in serum and cerebrospinal fluid. $J$ Med Virol 1985;15:183-95.

3 van Loon AM, Heessen FWA, van der Logt JTM. Isotype antibody response after human cytomegolovirus infection. $J$ Virol Methods 1987;15:101-7.

4 Dunn SD. Effects of the modification of transfer buffer composition and the penetration of proteins in gels on the recognition of proteins on western blots by monoclonal antibodies. Anal Biochem 1986;157:144-53.

5 Blake MS, Johnston KH, Russell-Jonas GJ, Gotschlich EC. A rapid sensitive method for detection of alkaline phosphate-conjugated anti-antibody on western blots. Anal Biochem 1984;136:175-9.

6 Hughes RAC, Winer JB. Guillain-Barré syndrome. In: Matthews WB, Glaser GH, eds. Recent advances in Clinical Neurology. New York: Churchill Livingstone, 1984:19-50.

7 Steiner I, Abramsky O. Immunology of Guillain-Barré syndrome. Springer Semin Immunopathol 1985;8: 165-76.

8 Pollard JD, Baverstock J, Mcleod JG. Class II antigen expression and inflammatory cells in the GuillainBarré syndrome. Ann Neurol 1987;21:337-41.
9 Dowling PC, Cook SD. Role of infection in GuillainBarré syndrome; laboratory confirmation of herpes viruses in 41 cases. Ann Neurol 1981;9(suppl):44-55.

10 Beghi E, Kurland LT, Mulder DW, Wiederholt WC. Guillain-Barré syndrome; clinicoepidemiological features and effect of influenza vaccine. Arch Neurol 1985;42:1053-7.

11 Kaslow RA, Sullivan-Bolyai JZ, Holman RC, Hafkin B, Dieker RC, Schonberger LB. Risk factors for GuillainBarré syndrome. Neurology 1987;37:685-8.

12 Seibert DG, Seals JE. Polyneuropathy after herpes simplex type 2 meningitis. South Med J 1984;77:1476.

13 Gerken G, Trautmann F, Köhler H, Falke D, Bohl J, Nix W, Meyer zum Büschenfelde KH. Rare association of herpes simplex virus IgM-specific antibodies and Guillain-Barré syndrome successfully treated with plasma exchange and immunosuppression. Klin Wochenschr. 1985;63:468-74.

14 Menonna J, Goldschmidt B, Haichi N, Dowling P, Cook S. Herpes simplex virus-IgM specific antibodies in Guillain-Barré syndrome and encephalitis. Acta Neurol Scand 1977;56:223-31.

15 Olivarius BF, Buhl M. Herpes simplex virus and GuillanBarré polyradiculitis. Br Med J 1975;1:192-3.

16 Eberle R, Mou SW. Relative titres of antibodies to individual polypeptide antigens of herpes simplex virus type I in human sera. $J$ Inf Dis 1983;148:436-44.

17 Eberle R, Mou SW, Zaiz JA. Polypeptide specificity of the early antibody response following primary and recurrent genital herpes simplex virus type 2 infections. J Gen Virol 1984;65:1839-43. 